\title{
CENCON 2019
}

4th IEEE Conference on Energy Conversion (CENCON 2019)

Royal Ambarrukmo Hotel, Yogyakarta, Indonesia 16-17 October 2019 


\section{CONTENTS}

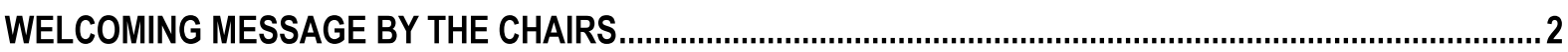

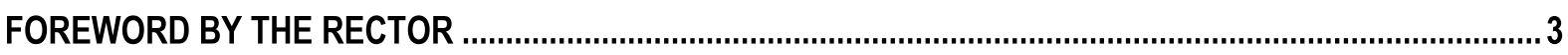

ORGANISING COMMITTEE

INTERNATIONAL ADVISORY COMMITTEE

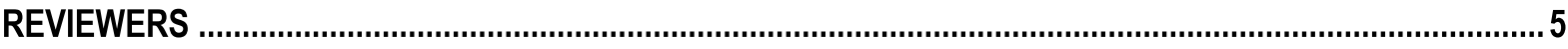

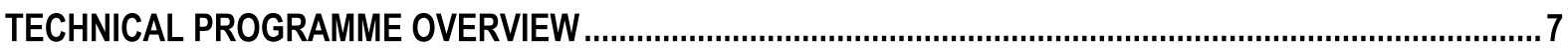

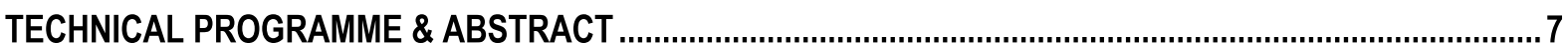

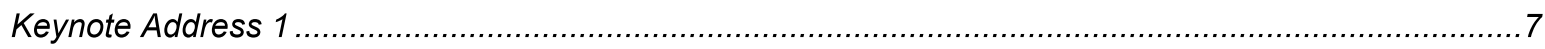

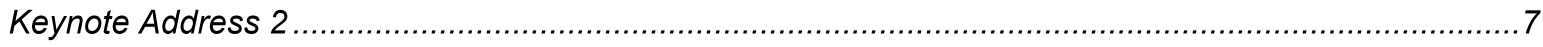

S1-1: Power Quality Room: Ball Room Karaton Time: 13:00 - 14:00 ............................................. 8

S2-1: Control of Power Electronics 1 Room: Pemandengan 1 Time: 13:00 - 14:00 ...........................

S3-1: Electrical Machine and Drives 1 Room: Pemandengan 2 Time: 13:00 - 14:00 ........................... 9

S4-1: Energy Harvest 1 Room: Pemandengan 3 Time: 13:00 - 14:00 ...........................................

S5-1: Renewable Energy 1 Room: Pemandengan 4 Time: 13:00 - 14:00 …......................................10

S1-2: Smart Grid and Power Engineering Room: Ball Room Karaton Time: 14:00 - 15:00 ...................11

S2-2: Control of Power Electronics 2 Room: Pemandengan 1 Time: 14:00 - 15:00 ............................11

S3-2: Electrical Machine and Drives 2 Room: Pemandengan 2 Time: 14:00 - 15:00 ...........................12

S4-2: Energy Harvest 2 Room: Pemandengan 3 Time: 14:00 - 15:00 .........................................13

S5-2: Renewable Energy 2 Room: Pemandengan 4 Time: 14:00 - 15:00 …......................................13

S1-3: Electric Vehicle Technology Room: Ball Room Karaton Time: 15:00 - 16:00............................14

S2-3: Power Converter Design 1 Room: Pemandengan 1 Time: 15:00 - 16:00 .....................................14

S3-3: Power Converter Design 3 Room: Pemandengan 2 Time: 15:00 - 16:00 ….............................15

S4-3: Multilevel Inverter 3 Room: Pemandengan 3 Time: 15:00 - 16:00 ….....................................16

S5-3: Renewable Energy 3 Room: Pemandengan 4 Time: 15:00 - 16:00 .........................................16

S2-4: Power Converter Design 2 Room: Pemandengan 1 Time: 16:00 - 17:00 ...................................17

AUTHORS INDEX

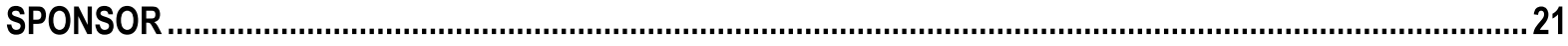




\section{ORGANISING COMMITTEE}

\section{General Chairs}

Tan Chee Wei, Universiti Teknologi Malaysia Nik Rumzi Nik Idris, Universiti Teknologi Malaysia

Tole Sutikno, Universitas Ahmad Dahlan

\section{Organising Chairs}

Mochammad Facta, Universitas Diponegoro

Shahrin Md. Ayob, Universiti Teknologi Malaysia

Mohd Amran Mohd Radzi, Universiti Putra Malaysia

\section{Technical Program Chairs}

Slamet Riyadi, Universitas Katolik Soegijapranata Ahmad Saudi Samosir, Universitas Lampung

Krismadinata, Padang Universitas Negeri Padang Mohd Rodhi Sahid, Universiti Teknologi Malaysia

Dodi Garinto, Politeknik Manufaktur Astra

\section{Finance and Registration Chairs}

Norjulia bt Mohamad Nordin, Universiti Teknologi Malaysia

Evrynda Widyasari Puspa Dewi, Universitas Ahmad Dahlan

\section{Publication Chairs}

Mohammad Nawawi Seroji, Universiti Teknologi MARA Md Pauzi Abdullah, Universiti Teknologi Malaysia Arwindra Rizqiawan, Institut Teknologi Bandung Nuryono Satya Widodo, Universitas Ahmad Dahlan Alfian Maarif, Universitas Ahmad Dahlan

\section{Local Arrangement Chairs}

Riky Dwi Puriyanto, Universitas Ahmad Dahlan Son Ali Akbar, Universitas Ahmad Dahlan Mohd Zaki Daud, Universiti Teknologi Malaysia

\section{Publicity and Website Chairs}

Phisca Aditya Rosyady, Universitas Ahmad Dahlan Awang Jusoh, Universiti Teknologi Malaysia

Nik Din Muhammad, Universiti Teknologi Malaysia

\section{Sponsorship and Exhibition Chairs}

Anton Yudhana, Universitas Ahmad Dahlan

Ahmad Raditya CB, Universitas Ahmad Dahlan

Mohd Junaidi Abdul Aziz, Universiti Teknologi Malaysia

Rahimi Baharom, Universiti Teknologi MARA

\section{Committees}

Nadia Tan Mei Lin, Universiti Tenaga Nasional Naziha Ahmad Azli, Universiti Teknologi Malaysia Refdinal Nazir, Universitas Andalas

Feri Yusivar, Universitas Indonesia

Estiko Rijanto, Lembaga Ilmu Pengetahuan Indonesia

Subiyanto, Universitas Negeri Semarang

\section{Secretariat}

Lina Handayani, Universitas Ahmad Dahlan

Afit Istiandaru, Universitas Ahmad Dahlan

Aan Hendroanto, Universitas Ahmad Dahlan

Adhi Prahara, Universitas Ahmad Dahlan

Nuril Anwar, Universitas Ahmad Dahlan

Ahmad Syafi'i Sulaiman, Institute of Advanced Engineering and Science

Arini Nur Rohmah, Institute of Advanced Engineering and Science

Azidanti Saufi, Institute of Advanced Engineering and Science

M. Iqbal Mulyadi, Institute of Advanced Engineering and Science

Ramadhan Bagus Hartanto, Institute of Advanced Engineering and Science

Septian Dwi Cahyo, Institute of Advanced Engineering and Science Zly Wahyuni, Institute of Advanced Engineering and Science

\section{INTERNATIONAL ADVISORY COMMITTEE}

Abdul Halim Mohd Yatim, Universiti Teknologi Malaysia, Malaysia

Azah Mohamed, Universiti Kebangsaan Malaysia, Malaysia Bhim Singh, Indian Institute of Technology (Delhi), India

Bimal K. Bose, University of Tennessee, US

Don Mahenda Vilathgamuwa, Nanyang Technological

University, Singapore

Fred C. Lee, Virginia Polytechnic Institute and State

University, US

Frede Blaabjerg, Aalborg University, Denmark Haitham Abu-Rub, Texas A\&M University, Qatar Iqbal Husain, North Carolina State University, US Jin Zhong, Hong Kong University, Hong Kong Kyo-Beum Lee, Ajou University, Korea Malik Elbuluk, University of Akron, US
Marian Kazmierkowski, Warsaw University of Technology and Polish Academy of Science, Poland

Mochamad Ashari, Institut Teknologi Sepuluh Nopember, Indonesia

Muhammad H. Rashid, University of West Florida, US

Nasrudin Abd Rahim, Universiti Malaya, Malaysia

Roland Bründlinger, Austrian Institute of Technology, Austria

Saifur Rahman, Virginia Polytechnic Institute and State University, US

Taufik, Cal Poly State University, US

Tim Green, Imperial College London, UK

Yanuarsyah Haroen, Institut Teknologi Bandung, Indonesia

Zainal Salam, Universiti Teknologi Malaysia, Malaysia 
state of the output power is predicted by the variation of the output power. It is calculated by the variation of output voltage and current of the PSFB-CT converter. As a result, the optimal phase-shift can be obtained. The effectiveness of proposed MPC method was proved by the simulation results.

14:20 The Impact of SRM Rotor Speed on Regenerative Braking to Optimize the Performance Anissa Firmana Dewi and Slamet Riyadi (Soegijapranata Catholic University, Indonesia)

Abstract: Switched Reluctance Motor (SRM) is an electric motor which is still being developed. SRM has various advantages offered, it can be used in various applications such as electric vehicles and so on. These advantages are allowing SRM to be applied in Electric Vehicles. Its is a technology which also developed in optimizing the performance of Electric Vehicles. Regenerative braking technology is reuse wasted energy in conventional braking as additional energy to the battery. It can maximize the performance and further the mileages of Electric vehicles. Variable speed during the braking period has a different impact on the performance of Regenerative Braking. This paper presents the impact caused by changes in speed on SRM motors. Changes in the speed produced by SRM affect changes in the current flowing into the battery. This method uses a constant PWM duty cycle. Laboratory tests have been conducted to confirm the proposed method.

\section{4:40 Implementation of Input Capture Method on Switched Reluctance Motor to Obtain Precise Commutation Signals Vincent Wijaya and Slamet Riyadi (Soegijapranata Catholic University, Indonesia)}

Abstract: Switched Reluctance Motor (SRM) is one of the modern electric motors. It has some advantages, such as high speed and low maintenance costs. To operate this motor, a microcontroller and rotor positioning sensor are required. Photoelectric transducer often used for determining rotor position. This sensor is installed at the end of motor shaft, with a rotary disk simultaneously. However, due to manual installation process, the photoelectric transducer could not give a precise signal. It also affects the commutation signals. As a solution to this problem, a new method has been developed. In this paper, the implementation of input capture on the dsPIC30F4012 microcontroller will be explained. By utilizing the input capture facility on dsPIC30F4012, commutation signals will be produced more precise.

S3-2: Electrical Machine and Drives 2 Room: Pemandengan 2 Time: 14:00 - 15:00

\section{4:00 Optimization of Single-Phase Induction Motor}

Mayuri Karpe (Kirloskar Brothers Limited, India); Santosh Ghosh and Naveen Shindhe (Kirloskar Brother Limited, India)

\footnotetext{
Abstract: Induction Motors are responsible for consumption of nearly $40 \%$ of electricity globally, as these are the driving force behind each fan, compressor, pump and nearly every mechanical load which have rotational motion. About 30 million new electric motors are put in use every year for industrial application alone. Despite the advent of permanent magnet based motors, single phase induction motors (SPIM) out numbers all other types of induction motors, because of its simple and robust construction and low cost. Hence small improvement in the performance of SPIM may greatly impact energy consumption worldwide and reduce carbon footprint eventually, however, studies related to SPIM is neglected by the researchers as these are not covered under the minimum efficiency standards. This paper presents design optimization technique of SPIM with the objective functions of maximization of efficiency while ensuring minimum material and tooling cost implication. For the current work a $0.5 \mathrm{hp}, 2$ pole motor has been considered as a sample case. Design approaches for optimization of capacitor start and run motor with the help of the double revolving theory is presented. The optimized design is validated by Finite Element Analysis and the predicted result of FEA analysis is compared with test result and found to be in good agreement.
}

14:20 Design and Simulation Permanent Magnet Synchronous Generator 1.5 kW for Ocean Current Turbine Danang Wijaya (UGM, Indonesia)

Abstract: The development of renewable energy is the main goal to reduce the use of fossil energy. This will have an impact on reducing environmental pollution such as air and water pollution. Deep ocean currents are renewable energy that can develop optimally. That is because the potential for deep ocean currents is very large. The characteristics of deep ocean currents have high current densities, so the power generated is also large. Also, turbines in a deep ocean current generator do not need land and deep ocean currents are easy to predict. So, that makes the cost calculation process easier and cheaper. The challenges in developing an ocean deep current power plant are very low current speeds and low maintenance of generators because it is difficult to reach. So, the permanent magnet synchronous generator (PMSG) is very appropriate to use. The characteristics of PMSG have a high enough efficiency, so it can be operated at low speeds. Also, maintenance from PMSG is very easy. In this paper, design a PSMG with $1.5 \mathrm{~kW}$ of power. The focus parameters are efficiency, power factor, cogging torque, and harmonics. While the parameters of the cooling system, mechanical pressure, etc. are ignored. PMSG design uses Ansys Maxwell software. The final result is obtained PMSG power capacity of $1.5 \mathrm{~kW}$ with 20 poles, 30 slots. PMSG rotational speed reaches $300 \mathrm{rpm}$ with an efficiency of $89 \%$. While cogging and harmonic torque is low value.

\section{4:40 High-Efficiency Flux Reference for Direct Torque Control of Induction Motor} Wee Yen Goh (Universiti Teknologi Malaysia UTM, Malaysia); Nik Rumzi Nik Idris and Norjulia Mohamad Nordin (Universiti Teknologi Malaysia, Malaysia); Auzani Jidin (Universiti Teknikal Malaysia Melaka, Malaysia)

Abstract: When a direct torque control (DTC) of an induction motor drive is operated below its rated torque, the stator flux reference has to be set to an optimised value (which is below its rated) in order to minimise the losses thus optimised its energy usage. The optimal flux will be calculated once the steady-state speed is reached and normally it will take some time before the new optimal flux is obtained. In this paper, an almost-optimal stator flux for a direct torque control (DTC) induction motor drive under lightloaded condition is calculated instantaneously. The high-efficiency flux reference (HEFR) scheme calculates the value of the stator flux reference, which is almost equal to the optimal flux reference, without having to wait for the steady-state speed. The proposed 


\section{The Impact of SRM Rotor Speed on Regenerative Braking to Optimize the Performance}

\author{
Anissa Firmana Dewi \\ Department of Electrical Engineering \\ Soegijapranata Catholic University \\ Semarang, Indonesia \\ anissafirmanaaaa@gmail.com
}

\author{
Slamet Riyadi \\ Department of Electrical Engineering \\ Soegijapranata Catholic University \\ Semarang, Indonesia \\ riyadi@unika.ac.id
}

\begin{abstract}
Switched Reluctance Motor (SRM) is an electric motor which is still being developed. SRM has various advantages offered, it can be used in various applications such as electric vehicles and so on. These advantages are allowing SRM to be applied in Electric Vehicles. It's is a technology which also developed in optimizing the performance of Electric Vehicles. Regenerative braking technology is reuse wasted energy in conventional braking as additional energy to the battery. It can maximize the performance and further the mileages of Electric vehicles. Variable speed during the braking period has a different impact on the performance of Regenerative Braking. This paper presents the impact caused by changes in speed on SRM motors. Changes in the speed produced by SRM affect changes in the current flowing into the battery. This method uses a constant PWM duty cycle. Laboratory tests have been conducted to confirm the proposed method.
\end{abstract}

Index Terms-Switched Reluctance, Electric vehicle, Regenerative braking, speed variable, optimal performance

\section{INTRODUCTION}

Electric vehicles have become a trend in the decade of 2000s. More than 350 electric vehicles are produced by the automotive industry around the world. The electric vehicle became a trend because of the capability to reduce air pollution which caused by conventional combustion engine systems. The regenerative braking system is one of the technologies that have been developed with the emergence of electric vehicles, to reduce the wasted energy and return it to the battery as additional power [1] [2].

In the electric vehicle industry, the BLDC motor is one of the electric motors that are often applied as an electric drive. However, in the electric motor based BLDC motor has disadvantages, for example, the permanent magnet and motor could be overheating. SRM motors are a substitute alternative to the use of a BLDC motor because SRM performance can produce higher speeds, lower maintenance costs, and especially the construction of a Switched Reluctance Motor circuit is simpler than a BLDC motor [3]. The classic converter from Switched Reluctance Motor is Asymmetric Converter. The asymmetric converter is capable to operate Regenerative Braking, because of its superiority to control phase leg independently. So, there is no short circuit on the power switch and it has the capability to boost the voltage [4] [5].
This paper proposes a regenerative braking method using variable speed control, to control the condition of battery charging in regenerative braking. The Switched Reluctance Motor works as a generator to produce voltage. The output voltage can be increased more than the battery voltage [6]. In this analysis is also equipped with an input capture system so that switching during braking is more precise. Laboratory test results show the higher rotational speed during braking, the more current entering the battery. This indicates that the proposed method in regenerative braking performance is optimum because it can operate in various speed range. The method can charge the battery even in low speed mode to high speed mode with constant duty cycle.

\section{ReseARch Method}

Switched Reluctance Motor has a salient pole rotor. Compared to other electric motors, SRM has some advantages where they can operate at variable temperature, others the rotor and stator are not permanent magnets makes this motor can be made with large size.

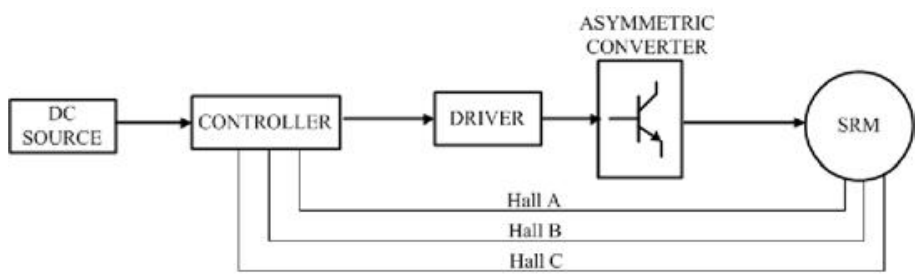

Fig. 1. Switched Reluctance Motor block diagram

Switched Reluctance Motor functional block diagram is shown in Fig. 1. Switched Reluctance Motor works based on differences in magnetic reluctance, the motor will receive a voltage source and then produce a magnetic field in the stator coil. The magnetic field from the stator coil would pull the rotor that in the nearest position [7]. The rotor and stator from Switched Reluctance Motor use in this paper is $12 / 8$, which means it has 12 stators and 8 rotors poles. The amount of stator and rotor, have an impact on motor speed and torque.

$$
T(\phi, i)=\frac{1}{2} i^{2} \frac{d L \phi}{d \phi}
$$




$$
V=i . R+\left(\frac{d \phi}{d i}+\frac{d i}{d t}\right)+\left(\frac{d \phi}{d \phi}+\frac{d \phi}{d t}\right)
$$

Equation 1. and Equation 2. are the Switched Reluctance Motor torque equation, where $(T)$ is the reluctance torque, $(i)$ is the current, $(v)$ is the voltage, and $(d \phi)$ is the magnetic flux. The decrease in inductance phase causes negative torque. Increase in inductance phase causes positive torque. Increase in inductance phase causes the amount of current would be increased. Therefore, phase change techniques are very required here. The phase change can be adjusted by controlling the switches [7] [8].

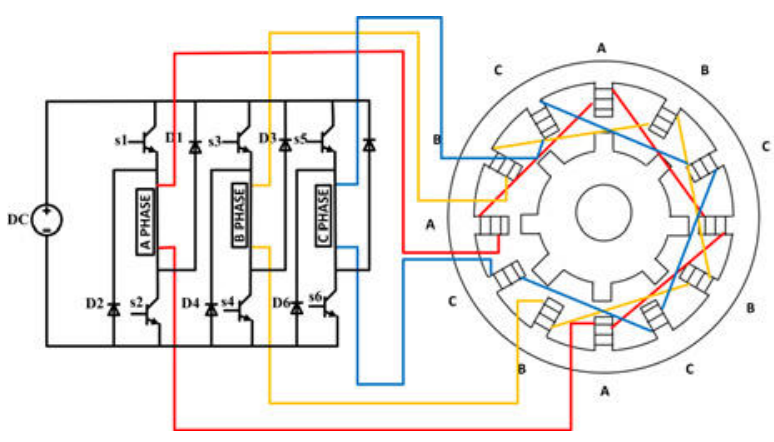

Fig. 2. Equivalent circuit of Switched Reluctance Motor including asymmetric converter circuit

Figure 2. is representing the construction of Switched Reluctance Motor which is connected to the asymmetric converter. Phase $\mathrm{A}$, phase $\mathrm{B}$, and phase $\mathrm{C}$ are representing stator winding. S1 - S6 are representing the static switch. D1 - D6 are representing freewheeling diodes. The asymmetric converter can control the phase leg independently. It is causing the asymmetric converter free of short circuit.

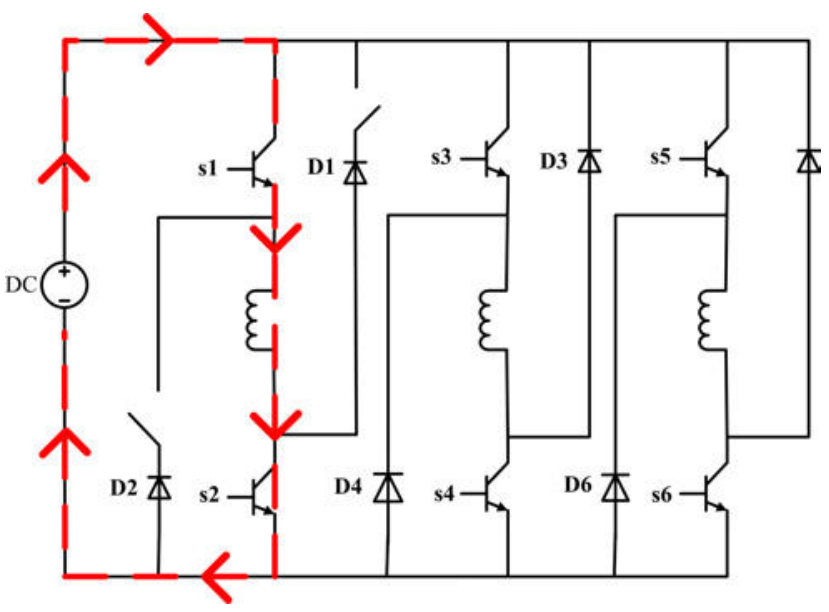

Fig. 3. Asymmetric Converter Motoring mode

Figure 3. is representing Asymmetric Converter on motoring mode. The current flows through $S 1$ to $S 2$ and then back to the battery. The position of the rotor is determined by using the optical encoder sensor.

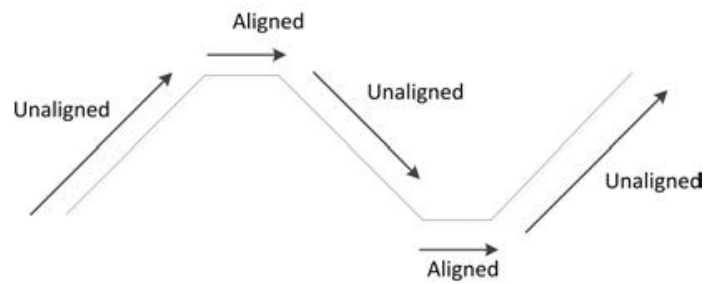

Fig. 4. Rotor and Stator position movement

Figure 4. is representing the condition of the rotor when aligned with the stator and the condition of the rotor when unaligned from the stator. The rotor rotation direction can be seen in Table 1.

TABLE I

RORATY ROTOR EXICATION TIMMING

\begin{tabular}{|l|l|l|l|l|l|l|}
\hline $\begin{array}{c}\text { Stator } \\
\text { Indicator }\end{array}$ & S1 & S2 & S3 & S4 & S5 & S6 \\
\hline $\begin{array}{c}\text { Phase A } \\
(011,100)\end{array}$ & ON & ON & OFF & OFF & OFF & OFF \\
\hline $\begin{array}{l}\text { Phase B } \\
(001,110)\end{array}$ & OFF & OFF & ON & ON & OFF & OFF \\
\hline $\begin{array}{l}\text { Phase C } \\
(010,101)\end{array}$ & OFF & OFF & OFF & OFF & ON & ON \\
\hline
\end{tabular}

Table 1. consists of the complement of binary numbers which indicate each phase on the stator.

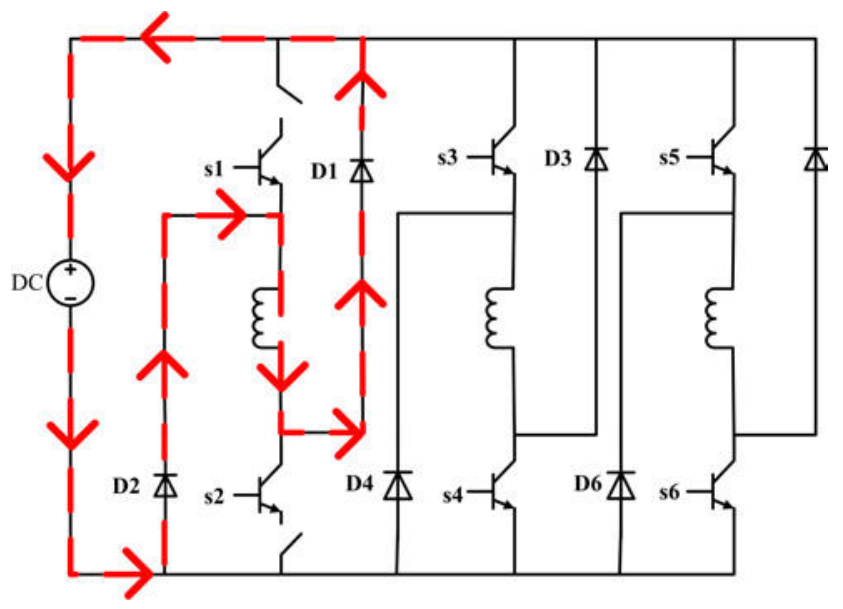

Fig. 5. Asymmetric Converter Generating mode

Figure 5. is explaining the current flows from D2 to the motor and continue to D1. In order to operate the braking system, Switched Reluctance Motor becomes the generator. It can be achieved by using the DC motor which the axis is connected with SRM. 


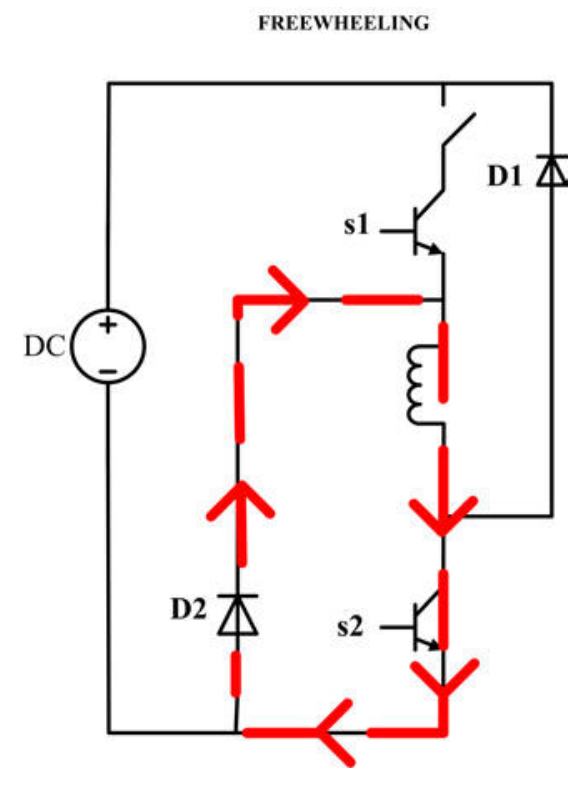

Fig. 6. Asymmetric Converter Freewheeling

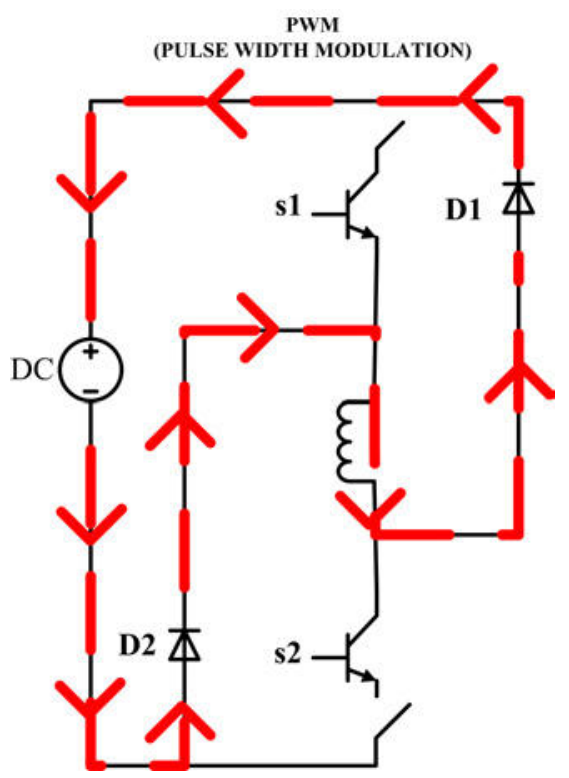

Fig. 7. Asymmetric Converter PWM mode

Regenerative braking of switched reluctance motor adopt two methods. The first method uses the single pulse method, it needs high speed of motor rotation. The second method implements the PWM (Pulse Width Modulation) method, it can operate from low to high speed [9]. This paper uses the PWM method to operate the proposed method. The PWM method makes the current is in freewheeling condition. Freewheeling condition is shown in Fig. 6. Stator commutation is controlled by a constant duty cycle which set in S2. S2 is in the ON / OFF state until the speed decreases gradually, shown in Fig.7. At this condition, the current flow which charged into the battery more optimal. This operation mode utilizes the chopper-boost work principle.

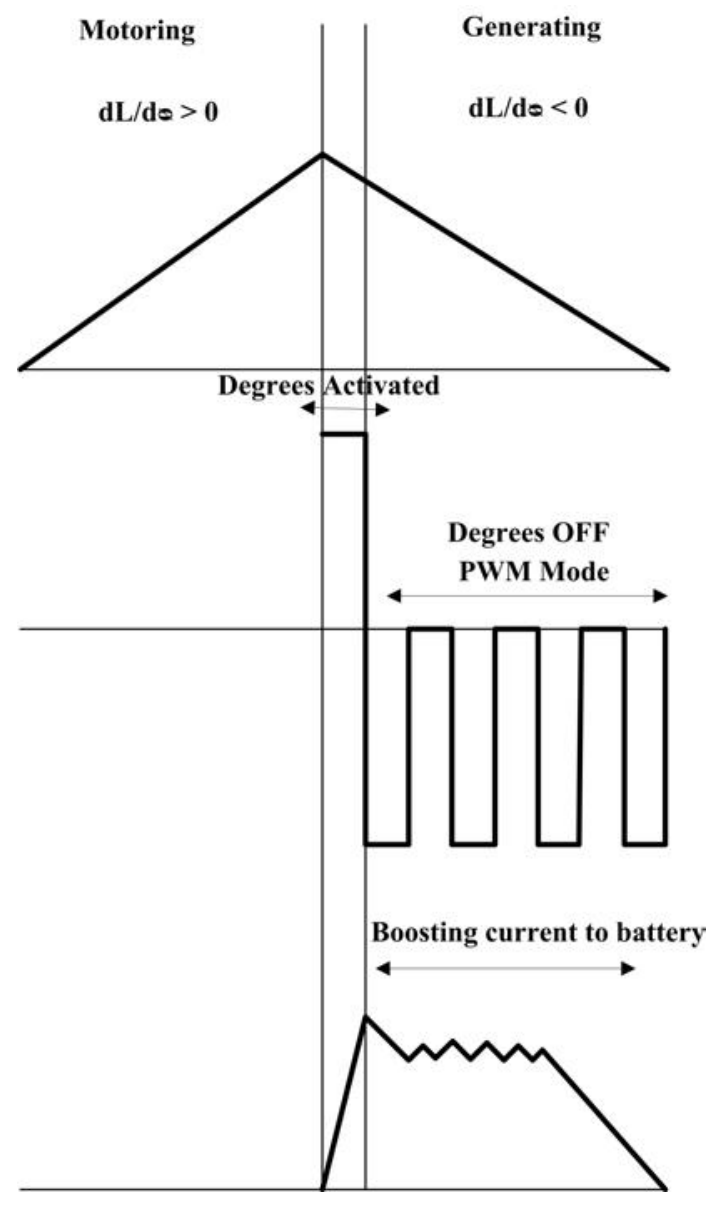

Fig. 8. Diagram of SRM functioned in regenerative braking mode

The maximum current wave that charged the battery can be seen in Fig. 8. It happens before the OFF switching. Input Capture facility in the dsPIC30F4012 microcontroller is used to achieve the proper commutation pattern. To determine the exact point of commutation is using Eq. 3. and Eq. 4. by using this method, the current flows make charging of the battery faster and can regenerate the energy into the additional power.

$$
\begin{gathered}
S_{A C T}=\frac{x^{\circ} O N * I C}{360} \\
S_{D E A C T}=\frac{x^{\circ} O F F * I C}{360}
\end{gathered}
$$

Variable $\left(x^{\circ}\right)$ is representing exact point where signal is activated and deactivated. Variable $(I C)$ is representing the total amount of electric degrees of reference signal. 


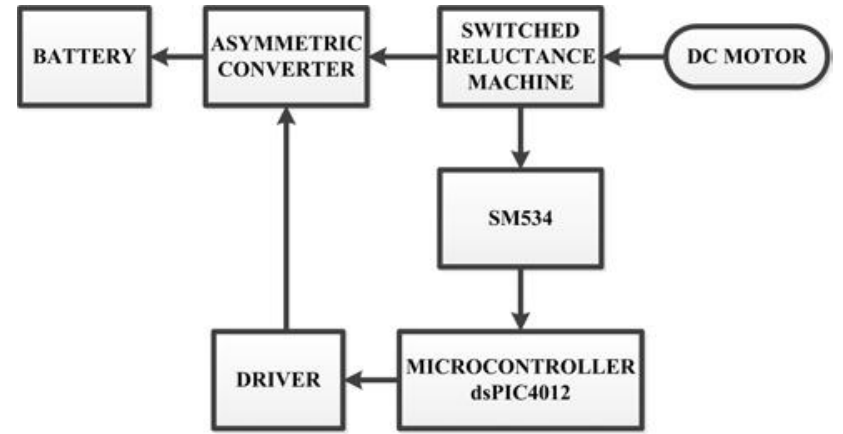

Fig. 9. Flowchart of the porposed system

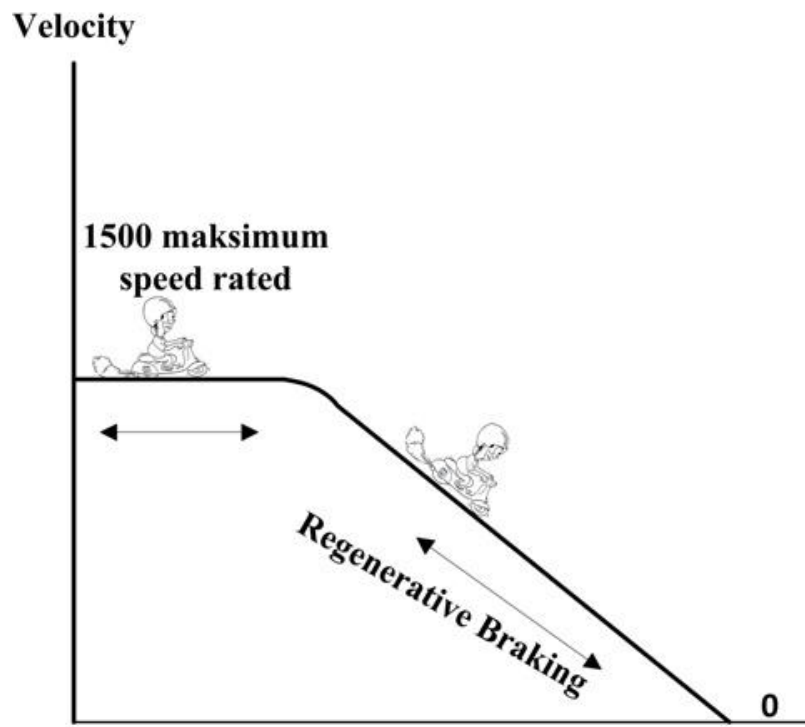

Fig. 10. Regenerative Braking illustration

Figure 10. shows a vehicle that runs constantly on a flat surface. Then the vehicle goes through a sloping surface which causes acceleration. Braking is done when the vehicle passes a sloping surface. Vehicle speed on sloping surfaces is reduced due to braking effects. Decreasing speed due to braking occurs gradually. SRM produces a current to charges the battery on this braking mode. The speed value of SRM is directly proportional to the value of the current flow into the battery. The current which charge the battery is controlled by the speed value produced by an electric vehicle. The proposed method is able to optimize the current flow into the battery, because it can operate in various speed ranges. The method can charge the battery even in low speed mode to high speed mode with constant duty cycle.

\section{RESUlT AND Discussion}

Switched Reluctance Motor which used in this method is consisting of 12 stators, 8 salient pole rotors, asymmetric converter, and SM534 sensor. The input of Input Capture is a digital signal from SM534. This Motor is controlled by Microcontroller dsPIC30F4012. The prototype of the proposed system can be seen in Fig. 10. In this section, the figure shows some results of the output signal with various different speeds rated. The specification of Switched Reluctance which used in this paper can be seen in Table 2 .

TABLE II

MOTOR SPECIFICATION

\begin{tabular}{|c|c|c|}
\hline Model & Hand Made & Unit \\
\hline Number of Poles & $12 / 8$ & - \\
\hline Number of Phases & 3 & - \\
\hline Rated Voltage & 30 & VDC \\
\hline Rated Speed & 1500 & RPM \\
\hline Rated Current & 0.8 & A \\
\hline Mass & 1000 & gram \\
\hline
\end{tabular}

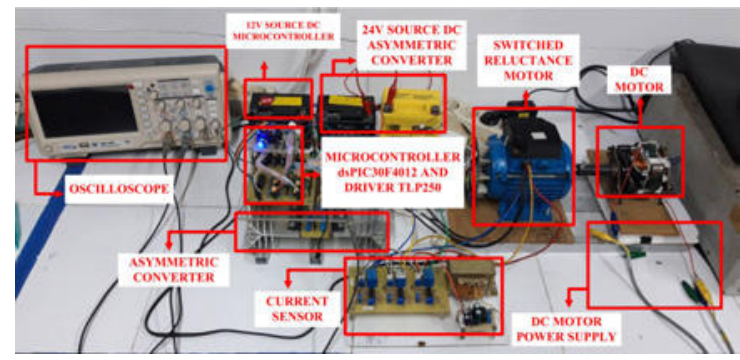

Fig. 11. The prototype for experimental works

Figure 11. shows that the DC motor is used to rotate Switched Reluctance Motor as a generator. SRM charge the battery and its speed will decrease gradually, it causes a braking effect on SRM. By using the other functions of the battery to stabilize the voltage, when regenerative braking happens the voltage result still constant and the current result changes according to braking conditions.

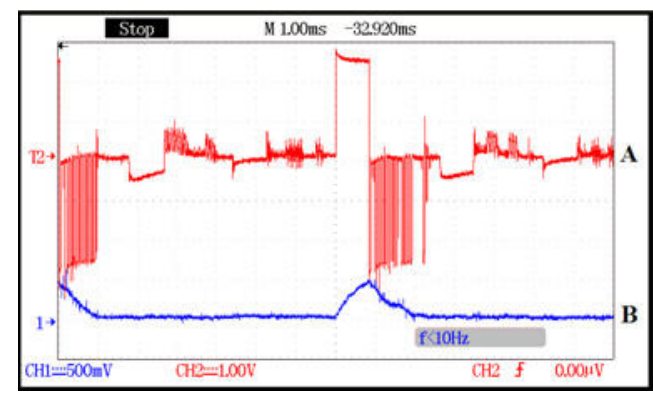

Fig. 12. The experimental results of phase A and output current waves while regenerative braking at $1109 \mathrm{rpm}$ (A) phase A (B) signal current entering the battery

The phase voltage and current waveforms which already processed by regenerative braking at 1109 rpm showed In Fig. 12. 


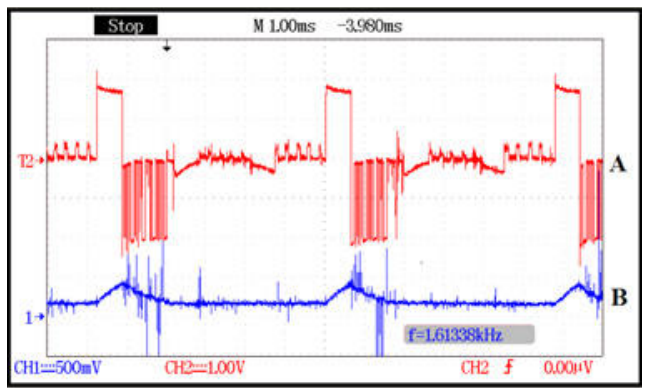

Fig. 13. The experimental results of phase $A$ and output current waves while regenerative braking at $1375 \mathrm{rpm}$ (A) phase A (B) signal current entering the battery

The phase voltage and current waveforms which already processed by regenerative braking at 1375 rpm showed In Fig. 13.

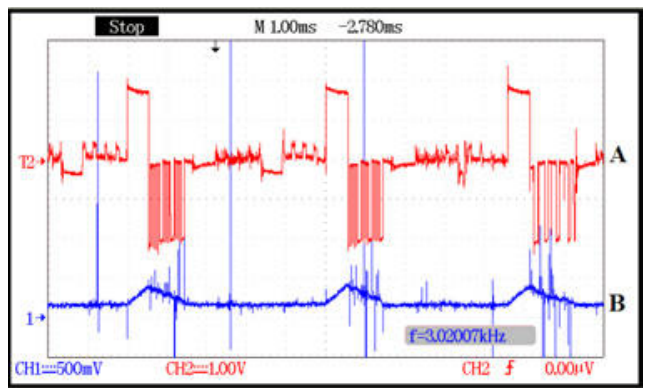

Fig. 14. The experimental results of phase $\mathrm{A}$ and output current waves while regenerative braking at $1438 \mathrm{rpm}$ (A) phase A (B) signal current entering the battery

The phase voltage and current waveforms which already processed by regenerative braking at 1438 rpm showed In Fig. 14.

The rotor operation is decreasing depends on the braking intensity. The higher of braking intensity, then the charging of the battery is more optimal.

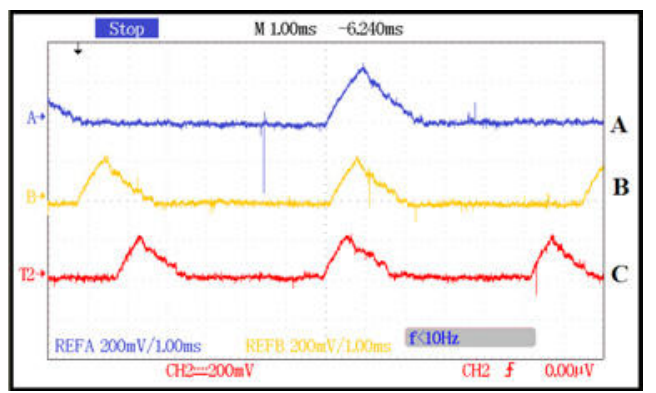

Fig. 15. The experimental results of regenerative braking current waves (A) signal that represent currents with a derivative speed of $1109 \mathrm{rpm}$, (B) signal that represent currents with a derivative speed of $1375 \mathrm{rpm},(\mathrm{C})$ signal represent currents with a derivative speed of $1438 \mathrm{rpm}$

Proper excitation angle to command the PWM turn ON while Switched Reluctance starts to braking, shown in Fig. 15. with the variable speeds have different impacts on the regenerative braking. The more precise angle was used to command the
PWM turn $\mathrm{ON}$ and make rotor rotation faster. Signal A, signal $\mathrm{B}$, and signal $\mathrm{C}$ have the different speed to start the regenerative braking, at the same time. Excitation angle on a signal $\mathrm{C}$ seen faster than signal $\mathrm{A}$ and signal $\mathrm{B}$, so the signal $\mathrm{C}$ can produce of regenerative braking is more optimal to the electric vehicle. Using the relationship between, reverse voltage $(e)$, angular speed $(\omega)$, current $(i)$ and flux magnetic $(d \phi)$.

$$
e=-\omega \cdot i \frac{d L}{d \phi}
$$

Equation 5. shown if $(\mathrm{e}<0)$ then the reverse voltage can't boost the current flow to the battery, if $(e>0)$ the reverse voltage increase then current flow boost to the battery. By using equation (5) and the experimental result in fig.15. proves that performance the regenerative braking on an electric vehicle gives the optimal impact on the current flow that charges the battery.

\section{CONCLUSION}

Based on the experimental results, this method can increase the current that flowing into the battery. Its method can work at the various speeds from low to higher that make the battery charging faster, it reinforces the impact on the electric vehicle braking and makes the regenerative braking performance are optimal. By using the SRM, the battery on electric vehicles more durable too. Current waves that charge into the battery and variable speeds can be seen in the experimental result which been described in this paper.

\section{ACKNOWLEDGMENT}

This work was supported by Directorate of Research and Community Service, Directorate General of Research Strengthening and Development, The Ministry of Research, Technology and Higher Education, Republic of Indonesia 2019.

\section{REFERENCES}

[1] B. Frieske, M. Kloetzke and F. Mauser, "Trends in vehicle concept and key technology development for hybrid and battery electric vehicles," 2013 World Electric Vehicle Symposium and Exhibition (EVS27), Barcelona, 2013, pp. 1-12. doi: 10.1109/EVS.2013.6914783

[2] S. S. Bhurse and A. A. Bhole, "A Review of Regenerative Braking in Electric Vehicles," 2018 International Conference on Computation of Power, Energy, Information and Communication (ICCPEIC), Chennai, 2018, pp. 363-367. doi: 10.1109/ICCPEIC.2018.8525157

[3] Z. Qianfan, C. Shumei and T. Xinjia, "Hybrid Switched Reluctance Motor Applied in Electric Vehicles," 2007 IEEE Vehicle Power and Propulsion Conference, Arlington, TX, 2007, pp. 359-363. doi: 10.1109/VPPC.2007.4544152

[4] P. Bogusz, M. Korkosz and J. Prokop, "Performance analysis of Switched Reluctance Motor with asymmetric stator," 2011 IEEE International Symposium on Industrial Electronics, Gdansk, 2011, pp. 661-666. doi: 10.1109/ISIE.2011.5984236

[5] Z. Qu, H. Wang, S. Tang, X. Wei and Q. Chen, "A new hybrid asymmetric and buck-boost fronted converter for SRM with active boost voltage capability," 2017 20th International Conference on Electrical Machines and Systems (ICEMS), Sydney, NSW, 2017, pp. 1-6. doi: 10.1109/ICEMS.2017.8056315

[6] Chen Hao and Song Qiushuang, "A switched reluctance variable speed generator," CCECE 2003 - Canadian Conference on Electrical and Computer Engineering. Toward a Caring and Humane Technology (Cat. No.03CH37436), Montreal, Quebec, Canada, 2003, pp. 467-470 vol.1. doi: 10.1109/CCECE.2003.1226439 
[7] K. Vijayakumar, R. Karthikeyan, S. Paramasivam, R. Arumugam and K. N. Srinivas, "Switched Reluctance Motor Modeling, Design, Simulation, and Analysis: A Comprehensive Review," in IEEE Transactions on Magnetics, vol. 44, no. 12, pp. 4605-4617, Dec. 2008. doi: 10.1109/TMAG.2008.2003334

[8] A. R. Haryawan, "Energy Efficient C-Dump Converter with Inductor for Switched Reluctance Motor," 2018 IEEE Student Conference on Research and Development (SCOReD), Selangor, Malaysia, 2018, pp. 1-5. doi: 10.1109/SCORED.2018.8710794

[9] P. Bogusz, M. Korkosz and M. Pilecki, "The impact of parameter control on the characteristics of switched reluctance motor designed for small electric vehicle drive," 2015 Selected Problems of Electrical Engineering and Electronics (WZEE), Kielce, 2015, pp. 1-4. doi: 10.1109/WZEE.2015.7394044 